\title{
AKTUALISASI REVOLUSI MENTAL DALAM \\ PENGELOLAAN DANA DESA \\ (ANALISIS TAFSIR EKONOMI Q.S.YUSUF [12]: 55)
}

\author{
Muhammad Amin \\ IAIN Syaikh Abdurrahman Siddik Bangka Belitung \\ Email: Neima_hamada25@yahoo.com
}

\section{Azima}

Sekolah Tinggi Ilmu Tarbiyah Al-Quran Al-Ittifaqiah

Email: Azimahimah2808@gmail.com

\begin{abstract}
Dana Desa are one of the most effective policies in village development with the completion of various kinds of infrastructure in the village. On the other hand, this policy caused side effects in the form of criminal acts of corruption against these funds. Through the interpretation of Q.S. Yusuf verse 55, the author offers the actualization of the spirit of mental revolution in the management of village funds through measures to strengthen integrity, increase professionalism, innovation, responsibility, and broaden horizons. Through these steps, the village fund policy can be implemented completely and right on target.
\end{abstract}

Keywords: Mental revolution, dana desa, interpretasion, Q.S. Yusuf verse 55.

\begin{abstract}
Abstrak
Dana desa menjadi salah satu kebijakan yang paling efektif dalam pembagunan desa dengan terselesaikannya berbagai macam infrastruktur di desa. Di sisi lain, kebijakan dana desa ini ternyata menimbulkan efek samping berupa penyalahgunaan dana tersebut. Melalui interpretasi Q.S. Yusuf ayat 55, penulis menawarkan aktualisasi semangat revolusi mental dalam pengelolaan dana desa melalui langkah-langkah pembangunan integritas, peningkatan profesionalitas, inovasi, tanggung jawab, dan perluasan wawasan. Melalui langkah-langkah tersebut, kebijakan dana desa dapat diterapkan secara utuh dan tepat sasaran.
\end{abstract}

Kata kunci: : Revolusi Mental, Dana Desa, Tafsir, Q.S. Yusuf ayat 55 


\section{A. PENDAHULUAN}

Program Dana Desa merupakan salah satu program unggulan pemerintah dalam melakukan pemulihan ekonomi di desa di era pandemi. ${ }^{1}$ Pada tahun-tahun sebelumnya, program ini diklaim telah membantu mewujudkan pembangunan di daerah dan infrastruktur lainnya. ${ }^{2}$ Akan tetapi, Indonesian Corruption Watch (ICW) justru memaparkan hasil yang bertolak belakang. ICW mencatat bahwa sektor anggaran desa merupakan salah satu sektor yang paling rawan dikorupsi. ${ }^{3}$ Menghadapi kondisi dilematis ini, penulis menawarkan sebuah kajian tafsir ekonomi melalui penafsiran QS. Yusuf ayat 55 tentang manajemen pengelolaan keuangan yang dilakukan oleh Nabi Yusuf as. ketika menjadi bendaharawan negara Mesir.

Program Dana Desa tahun 2021 difokuskan pada tiga prioritas yaitu pemulihan ekonomi nasional, pelaksanaan program prioritas nasional seperti pendataan desa, dan adaptasi kebiasaan baru atau desa aman COVID-19. 4 Tiga prioritas ini merupakan program yang sangat tepat pada kondisi pandemi yang berakibat pada melemahnya kekuatan ekonomi nasional. Pemulihan ekonomi nasional dapat berjalan jika ditopang dengan pulihnya ekonomi desa sebagai produsen utama berbagai kebutuhan ekonomi nasional.

Meskipun Dana Desa telah diatur sedemikian rupa dan difungsikan bagi pembangunan fisik dan ekonomi masyarakat desa, realita yang tampak di tengah masyarakat justru menunjukkan hal yang sebaliknya.

${ }^{1}$ Lihat misalnya pengalihan fungsi dana desa pada penanganan pandemic Covid-19 di Jawa Tengah. Lihat https://dispermadesdukcapil.jatengprov.go.id/berita/99-dana-desa-dimasapandemi-covid-19 diakses pada tanggal 13 Desember 2020.

2 Lihat https://republika.co.id/berita/ekonomi/desa-bangkit/ppr3h6423/mendes-presidenperintahkan-peningkatan-dana-desa diakses tanggal 13 Desember 2020.

3 Lihat https://nasional.kompas.com/read/2018/11/21/19000481/icw-ada-181-kasus-korupsidana-desa-rugikan-negara-rp-406-miliar diakses tanggal 13 Desember 2020

4 Lihat https://setkab.go.id/inilah-prioritas-penggunaan-dana-desa-tahun-2021/ diakses tanggal 13 Desember 2020 
Indonesia Corruption Watch mencatat bahwa dana desa merupakan sektor yang paling rawan disalahgunakan. Beberapa rekor buruk korupsi dana desa terjadi sejak tahun 2017. Bahkan pada tahun 2019, tercatat 46 kasus korupsi dari total 271 kasus merupakan kasus korupsi dana desa. ${ }^{5} \mathrm{Di}$ tahun 2020, kasus korupsi dana desa juga masih kerap menjadi headline pemberitaan media massa. ${ }^{6}$

Dana Desa memang menawarkan solusi cepat dalam pembangunan dan pemerataan ekonomi di desa. Pada sisi lain, ketidakmampuan mengelola dan memanfaatkan dana yang begitu besar dapat menjadi pemicu lahirnya tindak korupsi atau justru tidak teralokasikannya Dana Desa secara tepat sasaran. Sebagai solusi dari masalah dilematis di atas, maka tafsir ekonomi menjadi salah satu jawabannya.

QS. Yusuf (12): 55 dapat dijadikan panduan dalam pengelolaan dana desa. ${ }^{7}$ Hasil analisis terhadap ayat ini juga dapat dijadikan patokan dalam pengelolaan Dana Desa sehingga dapat mewujudkan revolusi mental yang digaungkan terus-menerus oleh pemerintah. Dalam kalimat yang lebih sederhana, analisis terhadap QS. Yusuf (12): 55 ini merupakan upaya untuk melahirkan konsep manajemen keuangan qurani sebagai aktualisasi revolusi mental dalam pengelolaan Dana Desa. Sebagai landasan dari kajian ini adalah firman Allah dalam QS. Yusuf (12): 55 yaitu:

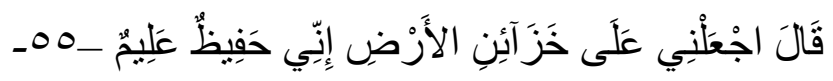

"Dia (Yusuf) berkata, "Jadikanlah aku bendaharawan negeri (Mesir); karena sesungguhnya aku adalah orang yang pandai menjaga dan berpengetahuan".

5 Lihat https://nasional.kompas.com/read/2020/02/18/19084421/catatan-icw-kasus-korupsidana-desa-terbanyak-muncul-pada-2019 diakses tanggal 13 Desember 2020

6 Lihat misalnya https://regional.kompas.com/read/2020/11/23/20523581/modus-kadesmerangin-korupsi-dana-desa-rp-339-juta-cairkan-uang-tapi diakses tanggal 13 Desember 2020 dan https://regional.kompas.com/read/2020/11/20/17434131/dana-desa-untuk-berfoya-foya-kades-inirugikan-negara-rp-317-juta diakses tanggal 13 Desember 2020.

7 Muhammad Quraish Shihab, Lentera al-Quran Kisah dan Hikmah Kehidupan, (Bandung: Mizan Pustaka, 2013), hlm. 319. 
Penjelasan lebih lanjut mengenai tafsir ayat ini dan juga bentuk implementasinya dalam kehidupan nyata akan penulis paparkan pada bagian-bagian berikutnya. Kajian ini berusaha mengungkap langkah apa saja yang perlu diterapkan dalam upaya implementasi manajemen keuangan qurani dalam pengelolaan Dana Desa untuk mewujudkan revolusi mental di Indonesia.

\section{B. DANA DESA SEBAGAI AKTUALISASI REVOLUSI MENTAL}

\section{Dana Desa: Pengertian dan Tujuannya}

Dana Desa merupakan frase yang tercipta dari penggabungan dua kata yaitu Dana dan Desa. "Dana” dapat diartikan sebagai pemberian, hadiah, derma, biaya, atau uang yang disediakan untuk suatu keperluan. ${ }^{8}$ Sementara "Desa" adalah kesatuan wilayah yang dihuni oleh sejumlah keluarga yang mempunyai sistem pemerintahan sendiri (dikepalai oleh seorang kepala desa). ${ }^{9}$

Istilah "Desa" berasal dari bahasa India swadesi yang berarti tempat asal, tempat tinggal, negeri asal, atau tanah leluhur yang merujuk pada satu kesatuan hidup dengan kesatuan norma serta memiliki batas yang jelas. Di Indonesia, istilah ini memiliki beberapa padanan yang digunakan secara berbeda di berbagai daerah seperti dusun bagi masyarakat Sumatera Selatan, dati di Maluku, kuta bagi masyarakat Batak, nagari di Sumatera Barat, atau wanua di Minahasa. Istilah "desa" juga merujuk pada konotasi mata pencaharian, norma dan adat istiadat. ${ }^{10}$

Secara etimologis, penggabungan dua kata Dana Desa akan menunjukkan arti uang yang disediakan untuk keperluan desa. Atau

8 KBBI Online. Lihat https://kbbi.kemdikbud.go.id/entri/Dana diakses tanggal 13 Desember 2020

9 Tanti Yuniar, Kamus Bahasa Indonesia, (T.t.p: Agung Media Mulia, t.t), hlm. 211.

10 Lihat Sumpeno Wahjudin, Perencanaan Desa Terpadu, (Banda Aceh: READ, 2011), hlm. 2-3. 
secara lebih tegas dijelaskan dalam Peraturan Pemerintah Republik Indonesia Nomor 60 Tahun 2014. Dana Desa diartikan sebagai dana yang bersumber dari Anggaran Pendapatan dan Belanja Negara yang diperuntukkan bagi Desa yang ditransfer melalui Anggaran Pendapatan dan Belanja Daerah kabupaten/kota dan digunakan untuk membiayai penyelenggaraan pemerintahan, pelaksanaan pembangunan, pembinaan kemasyarakatan, dan pemberdayaan masyarakat. ${ }^{11}$

Sejak pertama kali digulirkan pada tahun 2015, kebijakan Dana Desa terus meningkat hingga saat ini. Pada tahun 2015, Dana Desa yang dicairkan adalah Rp. 20,67 triliun, angka ini meningkat dua kali lipat pada thaun 2016 dengan jumlah dana sebesar Rp. 46,98 triliun, sementara pada tahun 2017 dan 2018 masing-masing dicairkan dana sebesar Rp. 60 triliun. Untuk tahun 2019, DPR RI telah menyepakati anggaran Dana Desa sebesar Rp. 70 triliun. ${ }^{12}$

Alokasi dana yang cukup besar tersebut digunakan untuk meningkatkan pelayanan publik di desa, mengentaskan kemiskinan, memajukan perekonomian desa, mengatasi kesenjangan pembangunan antardesa, serta memperkuat masyarakat desa sebagai subjek dari pembangunan. ${ }^{13}$ Tujuan yang dicita-citakan ini tampaknya menuai hasil positif. Pemerintah, melalui Kementrian Desa, Pembangunan Daerah Tertinggal, dan Transmigrasi Republik Indonesia, melansir berbagai torehan positif seperti dibangunnya $191.600 \mathrm{~km}$ jalan desa, 9.692 polindes,

11 Lihat Peraturan Pemerintah Nomor 60 Tahun 2014 Tentang Dana Desa Yang Bersumber Dari Anggaran Pendapatan Dan Belanja Negara Pasal 1 ayat 2.

12 Lihat https://www.kemenkeu.go.id/publikasi/berita/akumulasi-penyalurandana-desa-hingga-tahun-2018-tahap-2-mencapai-rp149-31-triliun/ diakses tanggal 18 April 2019 Lihat juga Hanif Nurcholis, Pertumbuhan dan Penyelenggaraan Pemerintah Desa, (Jakarta: Erlangga. 2011), hlm. 33.

13 Lihat Kementrian Keuangan Republik Indonesia, Buku Pintar Dana Desa: Dana Desa Untuk Kesejahteraan Rakyat, (Jakarta: Kementrian Keuangan Republik Indonesia, 2017), hlm. 14. 
28.820 unit posyandu, 8.983 pasar desa, 14 21.811 unit BUMDesa, 21.357 PAUD, dan berbagai pembangunan ini mampu menyerap tenaga kerja sejumlah lima juta jiwa hingga tahun 2017.15

Tren positif tersebut ternyata juga diiringi dengan meningkatnya kasus korupsi terkait alokasi Dana Desa. Berdasarkan pantauan ICW, terjadi peningkatan signifikan terhadap kasus korupsi Dana Desa. Pada tahun 2015 hanya terjadi 17 kasus korupsi, jumlah tersebut meningkat menjadi 41 kasus pada tahun 2016, sementara pada tahun 2017 terjadi 96 kasus korupsi terkait Alokasi Dana Desa. Mayoritas pelaku korupsi adalah kepala desa dengan rincian 141 orang kepala desa dari 184 koruptor yang tertangkap. ${ }^{16} \mathrm{Hal}$ ini memberikan signal negatif bahwa Indonesia sedang mengalami kekurangan kepala daerah yang amanah. ${ }^{17}$

Modus korupsi yang biasa dilakukan adalah: pertama, membuat rancangan di atas harga pasar. Kedua, mengklaim pembangunan fisik yang dibangun dengan dana proyek lain sebagai proyek Dana Desa. Ketiga, meminjam sementara Dana Desa untuk kepentingan pribadi namun tidak dikembalikan. Keempat, pemungutan atau pemotongan Dana Desa oleh oknum pejabat kecamatan atau kabupaten. Kelima, penggelembungan honor perangkat desa atau alat tulis kantor. Keenam, pemungutas retribusi tanpa diserahkan ke kas desa. Ketujuh, permainan proyek. Dan terakhir, proyek fiktif. ${ }^{18}$

${ }^{14}$ Lihat https://www.kemendesa.go.id/view/detil/2786/akibat-dana-desa-93-persen-desa-rutinselenggarakan-posyandu diakses tanggal 18 April 2019

15 https://www.kemendesa.go.id/view/detil/2227/dana-desa-lapangan-kerja-dan-kemiskinan diakses tanggal 18 April 2019

16 Lihat https://nasional.sindonews.com/read/1356283/13/dana-desa-rawan-korupsi-icw-141kepala-desa-jadi-tersangka-1542759428 diakses tanggal 18 April 2019, lihat juga https://www.antikorupsi.org/id/news/outlook-dana-desa-2018-potensi-penyalahgunaan-anggaran-desadi-tahun-politik diakses tanggal 18 April 2019

17 Sakdiah, Karakteristik Kepemimpinan Dalam Islam: Kajian Historis Filosofis SifatSifat Rasulullah", dalam Jurnal Al-Bayan / Vol. 22 No. 33 Januari - Juni 2016.

18 Lihat https://nasional.republika.co.id/berita/nasional/daerah/pnl37u428/delapan-moduspenyelewengan-dana-desa diakses tanggal 18 April 2019. 


\section{Revolusi Mental di Indonesia}

Gagasan Revolusi Mental merupakan usaha menghidupkan kembali semangat dan ide presiden pertama Republik Indonesia Soekarno. Gagasan ini mulai digaungkan kembali sejak tahun 2014.19 Segala kebijakan yang dilakukan oleh pemerintah dalam berbagai sektornya senantiasa diarahkan sebagai upaya perwujudan revolusi mental tersebut. Bahkan, revolusi mental saat ini dapat diakses secara maya melalui situs resmi pemerintah www.revolusimental.go.id.

Revolusi berarti perubahan yang cukup mendasar, ${ }^{20}$ sementara kata "mental" berarti yang menyangkut batin, watak atau yang bukan bersifat badan atau tenaga. ${ }^{21}$ Dari dua pengertian etimologis di atas, revolusi mental secara sederhana dapat dipahami sebagai perubahan watak dan batin yang cukup mendasar.

Pembangunan mental menjadi salah satu faktor utama dalam kebangkitan bangsa dan negara. Berbagai kajiah historis menunjukkan bahwa kehancuran peradaban dan kebudayaan negara-negara maju senantiasa dimulai akibat kerusakan mental pemerintah dan penduduknya. Sedikit sekali kehancuran bangsa yang disebabkan oleh perang fisik antar negara, justru sebaliknya, kehancuran bangsa terjadi akibat lemahnya mental para penguasa.

Gagasan revolusi mental pertama kali terlontar melalui lisan

19 Sigit Aris Prasetyo, Bung Karno dan Revolusi Mental, (Tanggerang Selatan: Imania, 2017), hlm. 10.

20 Revolusi juga diartikan sebagai perubahan ketatanegaraan (pemerintahan atau keadaan sosial) yang dilakukan dengan kekerasan seperti perlawanan bersenjata. Lihat Pusat Bahasa Departemen Pendidikan Nasional, Kamus Bahasa Indonesia, (Jakarta: Departemen Pendidikan Nasional, 2008), hlm. 1206.

${ }^{21}$ Pusat Bahasa Departemen Pendidikan Nasional, Kamus Bahasa Indonesia..., hlm. 942. Lihat juga Doni Koesuma, Pendidik Karakter di Zaman Keblinger, (Jakarta: Grasindo, 2009), hlm. 135. 
Presiden Soerkarno pada peringatan hari kemerdekaan 17 Agustus 1956. Pada kesempatan tersebut beliau menjelaskan bahwa revolusi mental berarti menjadi manusia yang berintegritas, mau bekerja keras, dan memiliki semangat gotong royong. Atau secara lebih tegas dapat diartikan sebagai suatu gerakan untuk menggembleng manusia Indonesia agar menjadi manusia baru, yang berhati putih, berkemauan baja, bersemangat elang rajawali, berjiwa api yang menyala-nyala. ${ }^{22}$

Melalui situs www.revolusimental.go.id, pemerintah menjelaskan delapan perinsip dasar revolusi mental yaitu: (1) revolusi mental adalah gerakan sosial untuk bersama-sama menuju Indonesia yang lebih baik, (2) harus didukung oleh tekad politik (political will) pemerintah, (3) harus bersifat lintas sektoral, (4) kolabrasi masyarakat, sektor privat, akademisi, dan pemerintah, (5) dilakukan dengan program "gempuran nilai" (value attack) untuk senantiasa mengingatkan masyarakat terhadap nilai-nilai strategis dalam setiap ruang publik, (6) desain program harus mudah dilaksanakan (user friendly), menyenangkan (popular) bagi seluruh segmen masyarakat, (7) nilai-nilai yang dikembangkan terutama ditujukan untuk mengatur moralitas publik (sosial), bukan moralitas privat (individual), (8) dapat diukur dampaknya dan dirasakan manfaatnya oleh masyarakat. ${ }^{23}$

Revolusi mental yang telah dipaparkan di atas pada dasarnya merupakan prinsip universal tentang perubahan menuju sesatu yang

22 “Revolusi Mental: Membangun Jiwa Merdeka Menuju Bangsa Besar," dalam https://www.kominfo.go.id/content/detail/5932/revolusi-mental-membangun-jiwa-merdeka-menujubangsa-besar/0/artikel_gpr, diakses tanggal 18 April 2019

23 http://revolusimental.go.id/revolusi/8-prinsip, diakses tanggal 18 April 2019. Lihat juga penjelasan tentang nilai-nilai revolusi mental dalam Asep Zaenal Ausop, Islamic Character Building, (Bandung : Salamadani, 2014), hlm 55. Bandingkan dengan Djudjun Djaenudin Supriadi, "Program Pendidikan Karakter di Lingkungan BPK PENABUR Jakarta," dalam Jurnal Pendidikan Karakter, Nomor 10, Tahun ke 7, Juni 2008, hlm. 35, dan Nana Rukmana, Bahan Ajar Diklat Kepemimpinan, (Jakarta: Lembaga Administrasi Negara Republik Indonesia, 2015), hlm. 7. 
lebih baik. Dalam hal ini Allah swt. telah menegaskan bahwa perubahan haruslah dimulai dari diri sendiri. Hal ini terdapat dalam firman Allah: ${ }^{24}$

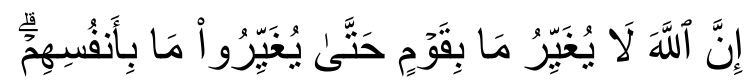

“...Sesungguhnya Allah tidak merubah keadaan sesuatu kaum sehingga mereka merubah keadaan yang ada pada diri mereka sendiri".

Ketika mengomentari ayat ini, Muhammad Quraish Shihab menggarisbawahi penggunaan kata qaum (kaum). Penggunaan kata ini menunjukkan bahwa perubahan yang terjadi adalah perubahan sosial, bukan perubahan individual. Penggunaan kata qaum ini juga mengindikasikan bahwa perubahan sosial mesti dilakukan oleh seluruh masyarakat, bukan hanya ras, agama, atau suku tertentu saja. ${ }^{25}$

Sebagai upaya mewujudkan revolusi mental ini dalam kehidupan nyata, khususnya jika dikaitkan dengan meningkatnya kasus korupsi Alokasi Dana Desa di Indonesia dengan penduduk mayoritas muslim terbesar se dunia, maka kajian teologis-normatif mutlak diperlukan. Kajian yang penulis lakukan adalah analisis tafsir ekonomi terhadap kisah Nabi Yusuf as. ketika mengajukan dirinya sebagai bendaharawan negara Mesir dan pola manajemen yang Nabi Yusuf terapkan sehingga mampu menjaga kondisi ekonomi Mesir di tengah labilnya kondisi ekonomi Timur Tengah pada saat itu.

\section{MANAGEMENT KEUANGAN QURANI DALAM KISAH NABI YUSUF}

\section{Nabi Yusuf sebagai Bendaharawan Negara}

\footnotetext{
Anfal (8): 53.

${ }^{25}$ Muhammad Quraish Shihab, Tafsir al-Misbah: Pesan, Kesan, dan Keserasian al-Quran, vol. VI, (Jakarta: Lentera Hati, 2012), hlm. 232.
}

${ }^{24}$ QS. Al-Ra'd (13): 11, ayat lain yang semakna dengan ayat ini terdapat dalam QS. Al- 
Nabi Yusuf as. merupakan salah seorang putra Nabi Ya'kub as. Ia di lahirkan di daerah Palestina sekitar tahun 1745 SM. Sebagian sumber lain menyatakan bahwa beliau lahir di Faddam Aram, Irak. ${ }^{26}$ Yusuf memiliki saudara kandung yang bernama Bunyamin dari ibu yang bernama Rahel. ${ }^{27}$ Sementara saudara tiri Yusuf berjumlah sepuluh orang yaitu Jad, Asyir, Dan, Deftail, Yasyjar, Robalen, Yahuza, Lewi, Syam'un dan Tobel. ${ }^{28}$

Yusuf adalah pemuda yang tampan dan juga dianugerahi oleh Allah SWT kecerdasan dalam mengelola keuangan negara (ekonomi) dan pandai mengungkapkan tabir mimpi. ${ }^{29}$ Kecerdasannya dalam mengungkapkan takwil mimpi telah dimilikinya sejak usia kecil. ${ }^{30}$ Ketika itu, ia bermimpi melihat bulan, matahari, dan 11 bintang bersujud kepadanya. Yusuf menakwilkan, petunjuk itu adalah akan bersujudnya ayah, ibu, dan ke-11 saudaranya kepada Yusuf. Khawatir akan membuat iri saudara tirinya, Ya'kub meminta Yusuf untuk menyimpan takwil mimpi tersebut. ${ }^{31}$

Kemampuan menakwil mimpi ini pulalah yang menjadi perantara dipilihnya Yusuf sebagai bendaharawan negara. Pada suatu ketika setelah sekian tahun Yusuf mendekam di penjara, raja Mesir bermimpi melihat tujuh sapi gemuk yang dimakan oleh tujuh sapi yang kurus, serta melihat tujuh tangkai gandum yang hijau serta tujuh tangkai gandum yang kering. Tak ada satupun ahli tabir mimpi kerajaan yang mampu mengungkapkan

\footnotetext{
${ }^{26}$ Fakhruddin ar-Razi, Tafsir Al-Kabir, Vol VIII, (Beirut: Dar Ihya' al-Turast al-Islami, 1995), hlm. 508.

27 A. Ya'kub Matondang, Tafsir Ayat-Ayat Kalam Menurut Al-Qadhi Abdul Jabbar, (Jakarta:, PT Bulan Bintang, 1989), hlm. 68.

28 Syauqi Abu Khalil, Atlas Alquran, (Bandung: Citra Pustaka Media,1993), hlm. 88.

29 Manna' al-Qatthan, Pembahasan Ilmu Al-Qur'an, (Jakarta: Rineka Cipta, 1995), hlm. 204.

${ }^{30}$ Muhammad Huesin Thabathaba'i, Mengungkap Rahasia al-Qur'an, (Bandung: Mizan, 1993), hlm. 209.

${ }^{31}$ Muhamad Mutawaly Sya'rawi, Min Washaya al-Qur'an al-Karim, (Kairo: al-Taufiqia, 1998), hlm. 178. Lihat juga Lihat Harun Yahya, Nabi Yusuf a.s. Terj. Akmal (Bandung: Sygma Publishing, 2008), hlm. 88.
} 
makna mimpi tersebut kecuali Yusuf as. Hal ini dikisahkan dalam firman Allah QS. Yusuf (12): 43.

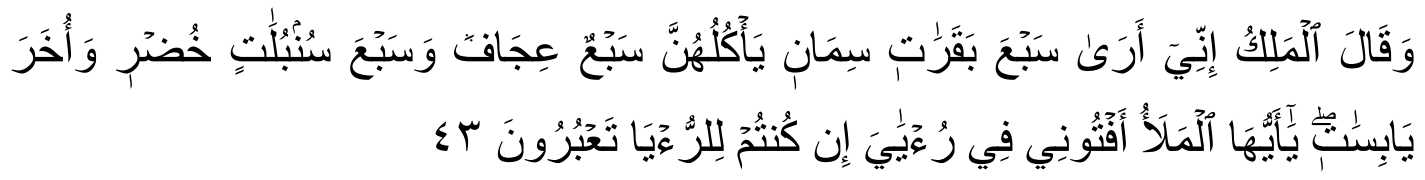

"Raja berkata (kepada orang-orang terkemuka dari kaumnya), "Sesungguhnya, aku bermimpi melihat tujuh ekor sapi betina yang gemuk-gemuk dimakan oleh tujuh ekor sapi betina yang kuruskurus dan tujuh tangkai(gandum) yang hijau dan tujuh tangkai yang kering. Hai orang-orang yang terkemuka, Terangkanlah kepadaku tentang tabir mimpiku itu jika kamu dapat menabirkan mimpi'."

Sudah menjadi kelaziman pada masa itu, apabila seorang bermimpi akan segera mencari tahu makna yang terkandung di dalam mimpi tersebut. Hal yang sama telah dilakukan oleh Yusuf ketika di masa mudanya ia bermimpi melihat sebelas bintang, matahari, dan bulan yang bersembah sujud kepadanya. Akan tetapi, tampaknya ada perbedaan antara mimpi biasa sebagai bunga tidur atau disebut adghas ahlam dengan mimpi yang memang merupakan pertanda hadirnya sesuatu. Pengungkapan tabir mimpi ini menjadi satu hal yang sangat penting di Mesir karena beberapa era setelahnya tradisi ini masih dipertahankan. Bahkan sebagian mufassir menjelaskan bahwa pembantaian anak-anak lakilaki dari kalangan Bani Isra'il yang dilakukan oleh Fir'aun adalah akibat dari takwil mimpi yang dialami oleh Fir'aun. ${ }^{32}$

32 Menurut Sayyid Ṭanțāwī, alasan kekejaman Fir'aun kepada Bani Isrā'îl adalah adanya seorang dari kaum Fir'aun yang mengabarkan kepadanya bahwa kelak ada seorang laki-laki dari Bani Isrā'îl yang akan menghancurkannya. Adapun Fir'aun yang berkuasa adalah Munfattāh bin Ramses II. Lihat, Sayyid Țanțāwī, al-Qișşah Fī al-Qur'ān al-Karìm, (Cairo: Dār Nahụatu Miṣr, 1996), hlm. 317. Al-Sa'labi sebagaiana dikutip oleh 'Ali al-Ṣābūnī menyebutkan bahwa kejadian itu disebabkan oleh mimpi Fir'aun yang melihat api yang menyambar dari Baitul Maqdis ke Mesir lalu melahap setiap bangunan dan hanya menyisakan bangunan-bangunan Bani Isrā'îl. Lihat 'Ali al-Ṣābūnī, Kenabian dan Para Nabi, terj. Arifin Jamian Maun (Surabaya: Bina Ilmu, 1993), hlm. 277. 
Namun entah mengapa, para pembesar dan penakwil mimpi yang ada di Mesir tidak bisa menangkap isyarat yang terdapat dalam mimpi raja sehingga mereka mengambil kesimpulan bahwa mimpi tersebut hanyalah bunga tidur belaka. Akan tetapi, Yusuf hadir di tengah kebingungan para penakwil mimpi dan menjelaskan bahwa akan datang tujuh tahun masa panen besar yang segera diiringi dengan tujuh tahun masa paceklik yang mengakibatkan tidak stabilnya ketersediaan pangan seluruh negeri-negeri Timur Tengah. Selain memberikan arti dari mimpi Raja, Yusuf as. juga memberikan solusi bagaimana mengatasi masalah tersebut. Hal ini dijelaskan dalam firman Allah QS. Yusuf (12): 47-49.

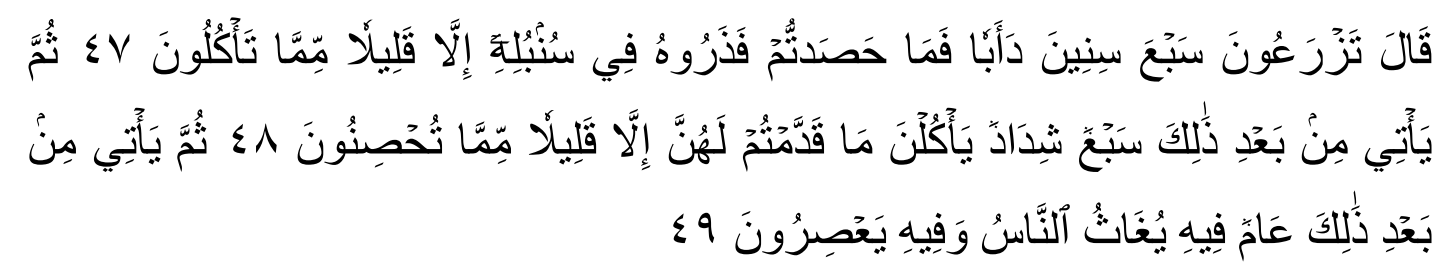

Yusuf berkata: "Supaya kamu bertanam tujuh tahun (lamanya) sebagaimana biasa; maka apa yang kamu tuai hendaklah kamu biarkan dibulirnya kecuali sedikit untuk kamu makan. Kemudian sesudah itu akan datang tujuh tahun yang amat sulit, yang menghabiskan apa yang kamu simpan untuk menghadapinya (tahun sulit), kecuali sedikit dari (bibit gandum) yang kamu simpan. Kemudian setelah itu akan datang tahun yang padanya manusia diberi hujan (dengan cukup) dan dimasa itu mereka memeras anggur."

Penjelasan yang diberikan oleh Nabi Yusuf as. mengenai mimpi tersebut adalah bahwa akan datang tujuh masa subur secara berturut-turut di Timur Tengah secara umum dan Mesir secara khusus. Kemudian setelah itu akan datang tujuh tahun masa paceklik. ${ }^{33}$ Selain memberikan takwil terhadap mimpi, Nabi Yusuf juga memberikan solusi terhadap masalah yang akan dihadapi tersebut. Solusi yang diberikan

33 Muhammad Rasyid Ridha, Tafsir al-Quran al-Hakim Vol. 12, (Mesir: al-Hai'ah alMishriyyah, 1990), hlm. 264. 
mencerminkan nilai-nilai utama yang dapat dijadikan patokan dalam menghadapi kesulitan ekonomi. Solusi tersebut adalah:

a. Kerja Keras: Yusf as. meminta masyarakat Mesir untuk bercocok tanam sebagaimana adat kebiasaan mereka selama tujuh tahun berturut-turut. Tentu pekerjaan tersebut harus dilakukan dengan baik dan konsisten. Bahkan pada masa paceklik sekalipun tetap harus diusahakan cocok tanam sebagaimana yang diindikasikan pada ayat ke-48.

b. Kerja Cerdas. Yusuf meminta agar pada tujuh tahun masa tanam, produk serta lahan pertanian harus ditingkatkan. Tidak membiarkan satu pun lahan kosong kecuali ditanami. Kemudian hasil dari panen gandum akan disimpan, bijinya akan dimakan oleh manusia sementara tangkainya diberikan untuk makanan hewanhewan seperti kuda dan unta. ${ }^{34}$

c. Kebersinambungan dan ketersediaan pangan: Sebuah kelaziman bagi masyarakat petani dimanapun untuk menikmati hasil panennya. Bahkan di Indonesia terkadang para petani tidak memiliki simpanan yang cukup karena mereka menjual hasil panen dan langsung membelanjakannya. Yusuf as. menginginkan adanya ketersediaan pangan sehingga hasil panen selama tujuh tahun akan tetap disimpan dan dibiarkan di tangkainya kecuali sebagian yang digunakan untuk konsumsi sehari-hari.

d. Keadilan dan Integritas. Ketika memasuki masa paceklik, hampir seluruh negeri di sekitar Mesir meminta bantuan dan pasokan makanan dari Mesir. Ketika kondisi tersebut terjadi, Yusuf menerapkan kebijakan hanya akan memberi satu karung gandum sesuai dengan jumlah individu dalam keluarga yang memohon.

${ }^{34}$ Kementrian Agama RI, Al-Qur'an dan Tafsirnya Vol V, (Jakarta: Percetakan Ikrar Mandiriabadi, 2011), hlm. 6. 
Artinya, ketersediaan dan kestabilan pangan harus lebih diutamakan daripada keuntungan ekonomi.

e. Ekspor bahan jadi. Setelah tujuh tahun masa paceklik maka akan hadir masa dimana masyarakat akan memerah buah-buahan menjadi minuman atau diambil sari minyaknya. Yusuf as. mengajarkan bahwa untuk meningkatkan kondisi ekonomi masyarakat adalah dengan mengubah bahan mentah seperti anggur dan zaitun menjadi produk olahan seperti perasan anggur atau minyak zaitun.

Kemampuan menyingkap tabir mimpi dan kecerdasan Yusuf dalam mengelola perbendaharaan negara serta ketersediaan pangan ini menjadikan ia diangkat sebagai bendaharawan negara Mesir. Firman Allah dalam QS. Yusuf (12): 54-55 menjelaskan hal ini:

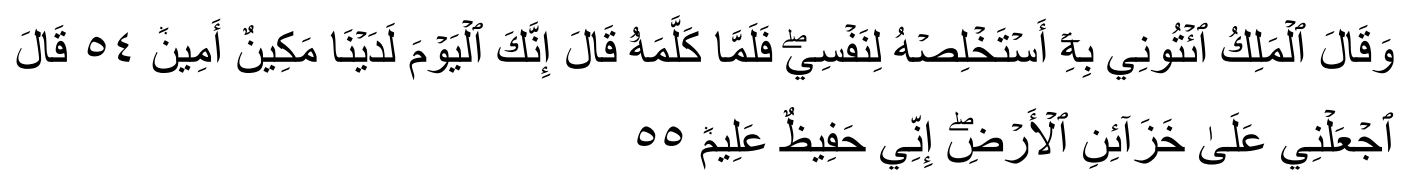

Dan raja berkata: "Bawalah Yusuf kepadaku, agar aku memilih dia sebagai orang yang rapat kepadaku". Maka tatkala raja telah bercakap-cakap dengan dia, dia berkata: "Sesungguhnya kamu (mulai) hari ini menjadi seorang yang berkedudukan tinggi lagi dipercayai pada sisi kami". Berkata Yusuf: "Jadikanlah aku bendaharawan negara (Mesir); sesungguhnya aku adalah orang yang pandai menjaga, lagi berpengetahuan"

Pada ayat di atas, dijelaskan bawah ada dua kriteria yang menjadikan Yusuf as. layak menduduki jabatan bendaharawan negara yaitu hafidzun dan 'alimun. Kata hafidzun tersusun dari tiga huruf dasar yaitu $h a, f a$, dan $d z a l$ yang menunjukkan arti terpeliharanya sesuatu, ${ }^{35}$ atau

${ }^{35}$ Ahmad ibn Faris, al-Mu'jam al-Maqayis al-Lughah (Beirut: Dar al-Fikr, t.t.), hlm. 275. 
seseorang yang diserahi sesuatu atau mampu menjaga sesuatu. ${ }^{36}$ Kata ini terulang sebanyak 44 kali dalam al-Quran.

Kata hafidzun menunjukkan sifat seseorang yang amat memelihara sesuatu, sanggup diserahi amanah bahkan mampu mengelola sesuatu yang ia jaga. Dalam ayat ini, kemampuan memelihara amanah dan menjaga sesuatu (hafidzun) lebih didahulukan dari pengetahuan dan wawasan ('alim). Hal ini menunjukkan bahwa dalam masalah pemerintahan atau masalah jabatan, kemampuan seseorang untuk menjaga dan mengelola lebih diutamakan daripada pengetahuannya. Karena seseorang yang mampu menjaga, memelihara dan mengelola akan termotivasi untuk menambah wawasan dan pengetahuannya. Sebaliknya, seseorang yang memiliki pengetahuan tanpa disertai sifat hafidzun akan cenederung menggunakan pengetahuannya untuk hal yang tidak benar. ${ }^{37}$ Contohnya adalah para pejabat yang memiliki gelar akademik yang tinggi namun tertangkap melakukan tindak pidana korupsi. Karena itu, konsep hafidzun mutlak diperlukan bagi setiap tenaga kerja.

Secara kebahasaan, kata 'alimun berarti orang yang mengerti atau banyak tahu. ${ }^{38}$ Kata ini berasal dari kata alima dan setiap kata dalam alQuran yang tersusun dari kata 'alima menunjukkan dua buah arti yaitu pengetahuan tentang sesuatu atau hukum tentang wujudnya sesuatu. Sementara kata 'alimun adalah sifat untuk manusia yang lebih tinggi derajatnya dari pada pemilik ilmu yang lain. ${ }^{39}$ Artinya, orang yang banyak tahu ('aliimun) lebih tinggi derajatnya daripada orang yang sekedar

36 Atabik Ali dan Ahmad Zuhdli Muhdlor, Kamus Kontemporer Arab - Indonesia (Yoryakarta: Multi Karya Grafika, t.t.), hlm. 781.

${ }^{77}$ Muhammad Quraish Shihab, Tafsir al-Mishbah: Pesan, Kesan, dan Keserasian al-Quran, vol. VI, (Jakarta: Lentera Hati, 2012), hlm. 127. Lihat juga Mushthafa al-Maraghi, Tafsir alMaraghi, vol. XII, terj. Anshori Umar Sitanggal dkk. (Semarang: Thoha Putra, 1994), hlm. 5. Bandingkan dengan Abdurrahman ibn Nashir al-Sa'dy, Taisir al-Karim al-Rahman fi Tafsir Kalami al-Mannan (Saudi: Al-Bayan, t.t.), hlm. 463.

${ }^{38}$ Atabik Ali dan Ahmad Zuhdi Muhdlor, Kamus Kontemporer... hlm. 1319.

${ }^{39}$ Q.S. Yusuf/12 : 76. 
memiliki pengetahuan ( $d z i$ 'ilmin) ${ }^{40}$ Menurut al-Marahi, kata 'alim dalam ayat ini berarti memiliki pengetahuan tentang bagaimana dan kemana harta itu akan dipergunakan. ${ }^{41}$

\section{Implementasi Manajemen Keuangan Qur'ani dalam Pengelolaan Dana Desa}

Kesejahteraan masyarakat desa merupakan suatu cita-cita mulia yang ingin diwujudkan oleh pemerintah melalui Alokasi Dana Desa. Akan tetapi tujuan ini juga harus disertai dengan manajemen keuangan, kontrol, serta pengelolaan yang baik. Kesejahteraan rakyat dapat diukur keberhasilannya dari beberapa variabel seperti keberlangsungan hidup, kemudahan akses, kecepatan pelayanan publik, serta sarana dan prasarana yang memadai. ${ }^{42}$

Pemerintah telah menyiapkan dana sebesar Rp. 70 triliun untuk Alokasi Dana Desa pada tahun 2019. Dana ini mestilah digunakan secara baik dan benar agar tujuan utamanya dapat tercapai dan tidak terjadi tindakan korupsi yang dapat menciderai cita-cita mulia ini. Berdasarkan analisis terhadap kisah Nabi Yusuf as. yang mampu melewati fase paceklik selama tujuh tahun dan bahkan mampu menolong negara-negara sekeliling Mesir pada masa paceklik, maka manajemen tersebut mestilah dijadikan sebagai pelajaran.

Sedangkan implementasi keuangan yang di dasari oleh Al-Qur'an seperti kisah pada Yusuf dalam mengelola keuangan negara yang berdasarkan pada kepandaian menjaga dan berpengetahuan dapat dijadikan sebuah ajaran untuk diteladani dalam mengelola keuangan,

40 Raghib al-Asfahani, al-Mu'jam al-Mufradat fi Alfadz al-Quran, (Beirut: Dar al-Kutub al-'Ilmiyyah, 2008), hlm. 384 - 385.

${ }^{41}$ Musthafa al-Maraghi, Tafsir al-Maraghi... vol. 12, hlm. 5.

42 Edi Suharto, Membangun Masyarakat Memberdayakan Rakyat, (Bandung: Refika Aditama, 2005), hlm. 71. 
khususnya kepala desa yang mengelola keuangan desa. Berikut langkahlangkah Implementasi QS Yusuf ayat 55 dalam mengelola keuangan desa, yaitu:

1. Membangun Integritas yaitu membangun mutu, sifat, atau keadaan yang menunjukkan kesatuan yang utuh sehingga memiliki potensi dan kemampuan yang memancarkan kewibawaan dan kejujuran. ${ }^{43}$ Integritas merupakan salah satu atribut terpenting/kunci yang harus dimiliki seorang pemimpin. Integritas adalah suatu konsep berkaitan dengan konsistensi dalam tindakan-tindakan, nilai-nilai, metode-metode, prinsipprinsip, dan berbagai hal yang dihasilkan. Orang berintegritas berarti memiliki pribadi yang jujur dan memiliki karakter yang kuat.

Integritas itu sendiri berasal dari kata latin "Integer", yang berarti: Sikap yang teguh mempertahankan prinsip, tidak mau korupsi, dan menjadi dasar yang melekat pada diri sendiri sebagai nilai-nilai moral.

2. Meningkatkan Profesionalitas. Profesionalitas secara garis besar merupakan kata sifat yang berarti karakter kerja seseorang dalam menekuni profesinya atau juga kemampuan untuk bertindak secara profesional. Jadi, sebagai pemimpin desa harus mampu meningkatkan profesionalitasnya yang bertujuan untuk kesejahteraan desa.

3. Bersifat Inovatif. yaitu memperkenalkan sesuatu yang baru dan selalu memiliki ide-ide yang mampu menciptakan suatu keadaan menjadi lebih baik bagi diri kita maupun masyarakat dan lingkungan sekitar.

43 Tim Penyusun Kamus Pusat Bahasa, Kamus Besar Bahasa Indonesia, ed.3-cet.4(Jakarta: Balai Pustaka,2007), hlm 208 
4. Mengedepankan Tanggung Jawab. Yaitu mampu menanggung segala sesuatu dari pekerjaan yang telah kita lakukan. Sebagai pemimpin maka harus selalu mengutamakan rasa tanggung jawab.

5. Memperluas Wawasan. Yaitu kemampuan untuk memahami cara-cara menyesuaikan diri atau menempatkan diri dalam lingkungan sosial, serta mengetahui hal-hal yang baru sehingga menciptakan suasana yang lebih baik.

Dengan mengimplementasikan lima prinsip tersebut maka tidak ada lagi penyelewengan dana di dunia politik, khususnya kepada kepala desa yang hanya mementingkan dirinya sendiri tanpa memikirkan kesejahteraan rakyatnya.

\section{KESIMPULAN}

Dari pemaparan di atas dapat disimpulkan bahwa manajemen keuangan qurani yang dijelaskan oleh Allah dalam kisah Nabi Yusuf as. QS. Yusuf (12): 55 dapat diimplementasikan dalam pengelolaan Dana Desa demi mewujudkan revolusi mental di Indonesia melalui langkah peningkatan integritas, peningkatan profesionalitas, inovatif, tanggung jawab, dan perluasan wawasan. 


\section{DAFTAR PUSTAKA}

Abdurrahman ibn Nashir al-Sa'dy, Taisir al-Karim al-Rahman fi Tafsir Kalami alMannan (Saudi: Al-Bayan, t.t.), hlm. 463.

Abu Khalil, Syauqi. Atlas al-Quran. Bandung: Citra Pustaka media. 1993.

Al-Ashfahani, Raghib. Al-Mu'jam al-Mufradat li Alfadzi al-Quran. Beirut: Dar alKutub al-'Ilmiyyah. 2008.

Ali, Atabik dan Ahmad Zuhdi Muhdlor. Kamus Kontemporer Arab-Indonesia. Yogyakarta: Multi Karya Grafika. T.T.

Ausop, Asep Zaenal. Islamic Character Building. Bandung: Salamadani. 2014.

Ibn Faris, Zakariyya. Al-Mu'jam al-Maqayis al-Lughah. Beirut: Dar al-Fikr. T.T.

Al-Maraghi, Ahmad Mushthafa. Tafsir al-Maraghi. Terjemah Anshori Umar Sitanggal. Dkk. Semarang: Toha Putra. 1994.

Kementrian Agama Republik Indoneisa. Al-Quran dan Tafsirnya. Jakarta: Kementrian Agama. 2011.

Kementrian Keuangan Republik Indonesia. Buku Pintar Dana Desa: Dana Desa Untuk Kesejahteraan Rakyat. Jakarta: Kementrian Keuangan Republik Indonesia. 2017.

Koesuma, Doni. Pendidikan Karakter di Zaman Keblinger. Jakarta: Grasindo. 2009.

Matondang, A. Ya'kub. Tafsir Ayat-Ayat Kalam Menurut al-Qadhi Abdul Jabbar. Jakarta: Bulan Bintang, 1989.

Nurcholis, Hanif. Pertumbuhan dan Penyelenggaraan Pemerintah Desa. Jakarta: Erlangga, 2011.

Peraturan Pemerintah Nomor 60 Tahun 2014 Tentang Dana Desa Yang Bersumber Dari Anggaran Pendapatan Dan Belanja Negara

Prasetyo, Sigit Aris. Bung Karno dan Revolusi Mental. Tanggerang Selatan: Imania. 2017.

Pusat Bahasa Departemen Pendidikan Nasional. Kamus Bahasa Indonesia. Jakarta: Departemen Pendidikan Nasional. 2008.

Al-Qatthan, Manna'. Pembahasan Ilmu al-Quran. Jakarta: Rineka Cipta. 1995. 
Al-Razi, Fakhruddin. Tafsir al-Kabir. Beirut: Dar Ihya' al-Turats al-Islami. 1995.

Ridha, Muhamad Rasyid. Tafsir al-Quran al-Hakim. Mesir: al-Hai'ah alMishriyyah. 1990.

Rukmana, Nana. Bahan Ajar Diklat Kepemimpinan. Jakarta: Lembaga Administrasi Negara Republik Indonesia. 2015.

Al-Sa'di, Abdurrahman ibn Nashir. Taisir al-Karim al-Rahman fi Tafsir Kalami alMannan. Arab Saudi: al-Bayan. T.T.

Sakdiah. "Karakteristik Kepemimpinan dalam Islam: Kajian Historis-Filosofis Sifat-Sifat Rasulullah. Dalam Jurnal al-Bayan. Volume 22 no. 33. JanuariJuni 2016.

Al-Shabuni, Ali. Kenabian dan Para Nabi. Terjemah Arifin Jamian Maun. Surabaya: Bina Ilmu. 1993.

Shihab, Muhammad Quraish. Tafsir al-Mishbah: Pesan, Kesan, dan Keserasian alQuran. Jakarta: Lentera Hati. 2012.

-------, Lentera Al-Quran: Kisah dan Hikmah Kehidupan. Bandung: Mizan Pustaka. 2013.

Suharto, Edi. Membangun Masyarakat Memberdayatak Rakyat. Bandung: Refika Aditama. 2005.

Supriadi, Djudjun Djaenudi. "Program Pendidikan Karakter di Lingkungan BPK PENABUR Jakarta". Jurnal Pendidikan Karakter. Nomor 10. Juni 2008.

Sya'rawi, Muhammad Mutawalli. Min Washaya al-Quran al-karim. Kairo: alTaufiqia,1998.

Tanthawi, Sayyid. Al-Qisshah fi al-Quran al-Karim. Kairo: Dar Nahdlatu Mishr. 1996.

Thabathaba'i, Muhammad Husein. Mengungkap Rahasia al-Quran. Bandung: Mizan. 1993.

Wahjudin, Sumpeno. Perencanaan Desa Terpadu. Banda Aceh: READ. 2011.

Yahya, Harun. Nabi Yusuf a.s. Terjemah Akmal. Bandung: Sygma Publishing. 2008.

Yuniar, Tanti. Kamus Bahasa Indonesia. TTP: Agung Mulia. T.T 
Web

http:/ / revolusimental.go.id http://www.djpk.kemenkeu.go.id/ https://kbbi.kemdikbud.go.id https://kemendesa.go.id/ https://nasional.kompas.com/ https://nasional.republika.co.id https://nasional.sindonews.com https://www.antikorupsi.org https://www.jawapos.com/ https://www.kominfo.go.id 